\title{
Dünyada ve Türkiye’de Ortaokul Öğretim Programlarının İklim Değişikliği Eğitimi Yaklaşımına Göre Karşılaştırılması*
}

\section{A Comparison of Secondary School Curricula in Terms of Climate Change Education in the World and Turkey}

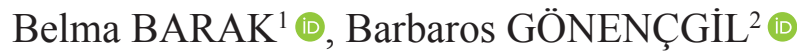

${ }^{1}$ Bartın Üniversitesi, Eğitim Fakültesi, Türkçe ve Sosyal Bilimler Eğitimi Bölümü, Bartın, Türkiye

${ }^{2}$ İstanbul Üniversitesi, Edebiyat Fakültesi, Coğrafya Bölümü, İstanbul, Türkiye

ORCID: B.B. 0000-0003-2275-7736; B.G. 0000-0001-6535-4481

\section{ÖZ}

İklim Değişikliği Eğitimi (IDE) son yıllarda kendi kimliğini oluşturmaya başlamış bir yaklaşımdır. Birçok ülke UNESCO'nun çağrısına uyarak küresel iklim değişikliğini, iDE yaklaşımına göre öğretim programlarına entegre etmeye başlamışlardır. Bu çalışmanın amacı PISA (2015) sınavında yüksek puan elde eden ülkelerin İklim, İklim Değiş̧ikliği, Küresel Isınma konularının verildiği ortaokul öğretim programlarını hedef (kazanım) açısından Türkiye öğretim programları ile karşılaştırmaktır. Çalışmada elde edilen veriler nitel araştırma yöntemlerinden doküman incelemesi yöntemi ile toplanmıştır. İklim ve iklim değişikliği ile ilgili konular iDE yaklaşımına uygun olarak Almanya, ABD, Avustralya, Kanada, İspanya, Güney Afrika Cumhuriyeti (GAC) ve Türkiye'de disiplinlerarası yaklaşımla verilirken İsveç'te disipliner yaklaşımla verilmektedir. Finlandiya ve İngiltere'de ise hem disipliner hem de multidisipliner dersler aracılığı ile öğrencilere aktarılmaktadır. IDE'nin bileşenlerinden biri olan “iklim değişikliğini yerel unsurlarla bütünleştirme” Finlandiya, İsveç, İspanya, Kanada, Almanya ve GAC öğretim programlarında yer alırken özellikle Finlandiya ve Avustralya'da kıtasal karşılaştırmalara da yer verilmektedir. ABD, İngiltere ve Türkiye'de ise sürdürülebilirlik konuları ve iklim değişikliğinin yerel etkileri yüzeysel olarak verilmektedir. Finlandiya'da Baltık bölgesinin çevre sorunlarına, GAC'da Afrika kıtasında yaşanan çevre sorunlarından özellikle su kıtlı̆̆ına, Avustralya'da ise Avustralya'nın ekolojik sorunlarına yer verilmektedir. Geçmiş dönem iklim değişikliklerini öğretebilmek IDE yaklaşımında öne çıkan bir hususken sadece İngiltere'de öğrenciler buzul çağından günümüze kadar yaşanan iklim değişikliklerini yorumlayabilmeyi öğrenmektedirler.

Anahtar kelimeler: Karşılaştırmalı Eğitim, İklim Değişikliği Eğitimi, Sürdürülebilir Kalkınma için İklim Değişikliği Eğitimi

\section{ABSTRACT}

Climate Change Education (CCE) is an approach that has started to establish its own identity in recent years. Many countries have begun to integrate global climate change into their curricula according to the CCE approach, following the UNESCO call. The aim of this study is to compare the curricula of Turkey with those of other countries which cover Climate, Climate Change, and Global Warming in terms of goal (gain). The countries and states with the highest scores in PISA (2015) were selected. The data obtained in this study were collected using the document analysis method as a qualitative research method. According to the CCE approach, issues related to climate and climate change are covered using an interdisciplinary approach in Germany, USA, Australia, Canada, Spain, Republic of South Africa (RSA) and Turkey while they are covered using a disciplinary approach in Sweden. In Finland and England, both disciplinary and interdisciplinary approaches are used with students. Establish a connection between local environmental issues and climate change, which is one of the components of CCE, can be found in the curricula of Finland, Sweden, Spain, Canada, Germany and RSA. In addition, comparison of the effects of climate change on the continents are made in the curricula of Finland and Australia. The topics of local effect of climate change and sustainability are cursory in the curricula of Turkey and USA. Curricula are focused on the environmental problems of the Baltic region in Finland, environmental problems in the African continent in RSA, especially water scarcity, and Australia's ecological problems in Australia. While teaching past climate changes is a highlight of the CCE approach, only students in the UK learn how to interpret climate changes from the ice age to the present.

Keywords: Comparative Education, Climate Change Education, Climate Change Education for Sustainable Development

*Bu makale, Belma Barak'ın Barbaros Gönençgil danışmanlığında yürütülen “Dünyada ve Türkiye'de İklim Değişikliği Eğitimi'nin İncelenmesi ve Bir Eğitim Modeli Önerisi" başlıklı doktora tezinden türetilmiştir.

Başvuru/Submitted: 30.09.2019 • Revizyon Talebi/Revision Requested: 03.10.2019 • Son Revizyon/Last Revision Received: 14.12 .2019 • Kabul/Accepted: 05.02.2019 - Online Yayın/Published Online: 09.06.2020

Sorumlu yazar/Corresponding author: Belma BARAK / belmabarak@bartin.edu.tr

Atıf/Citation: Barak, B. \& Gonencgil, B. (2020). A comparison of secondary school curricula in terms of climate change education in the world and Turkey. Cografya Dergisi. Advance online publication. https://doi.org/10.26650/JGEOG2019-0039 


\section{EXTENDED ABSTRACT}

According to reports of the IPCC's working groups, the education sector is the focus of the "climate change mitigation" and "climate change adaptation" strategies that are developed against the global climate change. Climate Change Education (CCE) is an approach that has started to form its own identity in recent years as part of Environmental Education (EE), Education for Sustainable Development (ESD) and Disaster Risk Reduction Education (DRRE). Many countries have continued to teach global climate change in their curricula with a single-disciplinary or multidisciplinary approach. However, many countries have begun to integrate global climate change into their curricula in line with the Climate Change Education approach, following the UNESCO call. The aim of this study is to compare the secondary school curricula of Turkey with those of other countries which cover Climate, Climate Change, Global Warming. The countries were selected from those countries that achieved high scores in Mathematics Literacy, Science Literacy and Reading Skills through the Program for International Student Assessment (PISA) in 2015. Curricula were examined in terms of goal (gain) and content regardless of discipline. The topics of climate, climate change, global warming in the curricula of Finland, Sweden, Spain, Canada, Australia, England, Germany, The United States of America (USA) and the Republic of South Africa have been examined based upon the 2015 PISA results. Although the Republic of South Africa did not participate in PISA 2015, the country was added to the list of countries whose curricula were examined due to the fact that it is located on the continent that is most affected by climate change. The curricula of the most successful states of Canada, Australia, Germany, Spain and the United States were selected for review based on the 2015 PISA results because of those countries not having national education programs. These states are British Columbia in Canada, Western Australia in Australia, Province of Castilla Leon in Spain, Bavaria in Germany and Massachusetts in the USA, respectively. A descriptive analysis study which examines curricula comparatively according to the climate change education approach was not found in the literature and there is a need for a curriculum designed in accordance with the Climate Change Education approach in Turkey. The study is important both to contribute to the literature and to shed light on the researchers who will develop the program according to this requirement. The data obtained from the study were collected via the document analysis method. The method of study is the descriptive approach from the comparative education model. According to the findings of the study, topics related to climate and climate change are taught with an interdisciplinary approach in Germany, the USA, Australia, Canada, Spain, Republic of South Africa and Turkey. Unlike the climate change education approach, it is taught in Sweden with a single-disciplinary approach. Topics related to climate and climate change are conveyed to the students using both single-disciplinary and multidisciplinary approaches in curricula in Finland and England. The integration of the effects of climate change with local events is one of the components of climate change education. This is included in the curricula of Finland, Sweden, Spain, Canada, Germany and Republic of South Africa while environmental problems caused by climate change are taught both on a local and regional scale in the curricula of Finland and Australia. Continental comparisons are also included. . Topics related to sustainability and local impacts of climate change are cursory in the curricula of the USA, England and Turkey.. Finnish curricula cover environmental problems of the Baltic region Republic of South Africa curricula cover environmental problems in Africa, especially water scarcity. Australian curricula cover the ecological problems of Australia. Sustainability and sustainable use of resources are included in the curricula of Germany, Sweden, Canada and the Republic of South Africa, especially projects related to sustainability are included in the curricula of Australia. Students are encouraged to take an active role in sustainability in Finland. Topics related to climate and climate change are taught based on Climate Change Education for Sustainable Development (CCESD) in the curricula of Germany, Finland, Spain and the Republic of South Africa. While teaching past climate changes is a highlight of the CCE approach, only students in the UK learn how to interpret climate changes from the ice age to the present. 


\section{GÍRIŞ}

Birleşmiş Milletlerin son 30 yılda düzenlediği konferanslardan ve yayımladıkları raporlardan da anlaşılacağı üzere iklim değişikliği her bir bireyin karşı karşıya kaldığ en önemli çevre meselesidir. İklim değişikliği ile ilgili kaygılar arttığından eğitim, bu sorunu çözmek için bir yöntem olarak hedeflenmiştir (United Nations Environment Programme [UNEP], 2006). Eğitim, iklim değişikliğiyle ilgili farkındalığı arttırırken bireylerde davranış, değer ve tutum değişikliklerini sağlayabilme ve bireylerin iklim değişikliğinin çeşitli sosyal ve çevresel etkilerine başarıyla uyum sağlamasına yardımcı olur (UNEP, 2006; United Nations Educational, Scientific and Cultural Organization [UNESCO] ve UNEP, 2011). Birleşmiş Milletler İklim Değişikliği Çerçeve Sözleşmesi'nin (United Nations Department of Public Information [UNDPI], 1994) 6. maddesi, ülkelerin eğitim, öğretim ve kamu farkındalığını dikkate alarak iklim değişikliği eğitimini teşvik etmesini ve insanların iklim değişikliği konusundaki farkındalığını arttırmasını istemektedir. Küresel iklim değişikliğinin yaratacağ 1 çevresel, ekonomik ve siyasi geleceğin belirsizliğiyle başa çıkabilecek donanımlı bireylere ihtiyaç duyulmaktadır. İklim değişikliğine karşı artan endişe de bu donanımlı bireylerin yetişebilmesini sağlayacak eğitim yaklaşımlarına duyulan gereksinimi vurgulamaktadır (Bangay ve Blum, 2010). İklim Değişikliği Eğitimi yaklaşımı hem Çevre Eğitimi'nin, hem Sürdürülebilir Kalkınma Eğitimi'nin hem de Afet Riski Azaltma Eğitimi'nin bir parçası olarak son yıllarda kendi kimliğini oluşturmaya başlamıştır (Mckeown ve Hopkins, 2003; Læssøe vd., 2009; Anderson, 2010; Robinson, 2011; Nazir, Pedretti, Wallace, Montemurro ve Inwood, 2011; UNESCO ve UNEP, 2011; Kagawa ve Selby, 2012; Tong, Shaw ve Takeuchi, 2012; Ho ve Seow, 2015; UNESCO, 2015; Mochizuki ve Bryan, 2015). İklim değişikliği ile mücadele için eğitim sistemini geliştirmeyi amaçlayan iklim değişikliği eğitimi, ilkokul ve ortaokul kademelerinde öğrenim gören öğrenciler arasında iklim değişikliği bilgisini geliştiren temel bir yaklaşımdır (Oversby, 2015; Mochizuki ve Bryan, 2015). İklim değişikliği eğitiminin amacı ise; iklim sisteminin temel ilkelerini anlayan, iklim hakkında bilimsel olarak güvenilir bilgiyi nasıl değerlendireceğini bilen, iklim değişikliğinin etkilerini en aza indirebilecek bilinçli kararlar alabilen ve sürdürülebilir toplumların sağlanmasına yardımcı olacak şekilde hareket eden çevresel tutum ve davranışları gelişmiş iklim okuryazarı bireyler yetiştirmektir (UNESCO, 2009a; Mochizuki ve Bryan, 2015; UNESCO, 2015). İklim okuryazarı bir birey "Dünyanın iklim sisteminin temel prensiplerini anlayan, iklim ile ilgili bilimsel olarak güvenilir bilgilerin nasıl değerlendirileceğini bilen, iklim ve iklim değişikliği hakkında anlamlı bir şekilde iletişim kuran. iklimi etkileyebilecek eylemler konusunda bilinçli ve sorumlu kararlar verebilen" bir birey olarak tanımlanmaktadır (United States Global Change Research Program [US GCRP], 2009).

İklim değişikliği eğitimi son yıllarda kendi kimliğini oluşturmaya başlamış bir yaklaşım olduğundan henüz standart bir öğretim programından söz etmek mümkün değildir. Ancak çalışmada ülke programlarının analizinde de yararlanılan İklim değişikliği eğitimi ile ilgili önemli gelişmeler kaydetmiş bilim insanlarının ve UNESCO, UNEP, NOAA (National Oceanic and Atmospheric Administration) gibi kuruluşların ortaya koyduğu bazı ilkelerden ve bileşenlerden söz etmek mümkündür.

NOAA iklim sistemini çerçeveleyerek 7 temel ilke belirlemiştir (US GCRP, 2009):

(1) Güneş, Dünya'nın iklim sistemi için temel enerji kaynağıdır.

(2) İklim, Dünya sisteminin bileşenleri arasındaki karmaşı etkileşimlerle düzenlenir.

(3) Dünya üzerindeki yaşam iklime bağlıdır, iklim tarafından şekillenir ve iklimi etkiler.

(4) İklim, doğal ve beşeri süreçler vasıtasıyla zaman ve mekan üzerinde değişir.

(5) İklim sistemine ilişkin anlayışımız gözlem, teorik çalışmalar ve modelleme yoluyla geliştirilmiştir.

(6) İnsan faaliyetleri iklim sistemini etkilemektedir.

(7) İklim değişikliğinin hem Dünya üzerine hem de insan yaşamı üzerine sonuçları olacaktır.

İklim değişikliği eğitiminin bileşenleri ise aşağıdaki şekliyle özetlenebilir:

(1) İklim Değişikliği Eğitimi yaklaşımına uygun olarak iklim ve iklim değişikliği konularını içeren dersler disiplinlerarası olarak verilmelidir (Niepold, Herring ve McConville, 2008; UNESCO, 2009a; UNESCO, 2009b; Wise, 2010; Robinson, 2011; Johnson, 2011; National Research Council, 2011; UNESCO ve UNEP 2011; Anderson, 2012; Kagawa ve Selby, 2012; Alexandru, Ianculescu, Tudora ve Bica, 2013; Mochizuki ve Bryan, 2015; Nussbaumm vd., 2015).

(2) İklim ve İklim Değiş̧ikliği ile ilgili hedef-kazanımlar öğrencilerde kavram yanılgılarına yol açmayacak biçimde düzenlenmelidir (McKeown ve Hopkins, 2010; Wise, 2010; Pruneau, Khattabi ve Demers, 2010; Robinson, 2011; Shepardson, Niyogi, Roychoudhury ve Hirsch, 2012).

(3) İklim değişikliğinin süreç ile ilişkisini öğretebilmek için öğrenciye yaparak-yaşayarak öğrenme faaliyetleri 
sunulmalıdır (Pruneau vd., 2001; McKeown ve Hopkins, 2010; Shepardson vd., 2012).

(4) İklim Değişikliğinin etkileri yerel ve bölgesel olaylarla ilişkilendirilmelidir (Mckeown ve Hopkins, 2003; Pruneau, Gravel, Bourque ve Langis, 2003; UNESCO, 2009a; Anderson, 2012; McKeown ve Hopkins, 2010; McKeown ve Hopkins, 2010; Shepardson vd., 2012; Nussbaum vd., 2015; UNESCO, 2015).

(5) İklim değişikliği eğitimi yaklaşımına uygun pedagojiler ve etkili materyaller içermelidir (UNESCO, 2009a; Khalid, 2003; Choi, Niyogi, Shepardson ve Charusombat, 2010; Nussbaum vd., 2015; Anderson, 2012; UNDPI, 1994; United Nations Conference on Environment and Development [UNCED], 1992; Haslett, Skellern, Chilcott ve Longman, 2010).

(6) İklim değişikliği eğitimi kaynakların sürdürülebilir kullanımını içermelidir (UNESCO, 2009a; Læssøe vd., 2009; Anderson, 2010; Nazir vd., 2011; Kagawa ve Selby, 2012; Anderson, 2012; Makrakis, Larios ve Kaliantzi, 2012; Alexandru vd., 2013; Mochizuki ve Bryan, 2015; UNESCO, 2015).

Sürdürülebilir kalkınmaya yönelik endişelerin artmasıyla BM “Sürdürülebilir Kalkınma İçin Eğitim On y1lı “ (2005-2014) programını başlatılmıştır (Alexandru vd., 2013). On yılın iddialı hedefi, sürdürülebilir kalkınmanın prensiplerini, değerlerini ve uygulamalarını, eğitim ve öğrenmenin tüm yönlerine entegre etmektir (Læssøe vd., 2009). UNESCO, BM Sürdürülebilir Kalkınma için Eğitim On Yılı sürecinin (2005-2014) ikinci yarısında Sürdürülebilir Kalkınma Eğitiminin amiral gemisi programı olarak "Sürdürülebilir Kalkınma için İklim Değişikliği Eğitimi” programını başlatmıştır (Mochizuki ve Bryan, 2015). Çünkü Sürdürülebilir Kalkınma için Eğitim On Yılı'nın 2005 yılındaki başlangıcından bu yana, iklim değişikliğinin hızlanması konusundaki artan farkındalık ve insan varlığına yönelik potansiyel tehditler, çevre sorunları için artan bir endişeye yol açmıştır (Læssøe vd., 2009). Program özellikle bireylerin iklim değişikliğinin etkisini anlamasına ve iklim okuryazarlığını artırmaya yardımcı olmayı amaçlamaktadır (UNESCO, 2015). İklim değişikliğinin kapsamlı bir şekilde okul müfredatlarına entegre edilmesi iklim değişikliğini hafifletme ve iklim değişikliğine uyum sağlama stratejilerine de katkı sağlayacaktır (UNESCO, 2015). UNESCO (2015), özellikle müfredat geliştirme uzmanlarının iklim değişikliğinin çok disiplinli niteliğini anlayarak ulusal ve yerel unsurlarla ilişkilendirilmiş ve müfredata entegre edilebilecek bir eğitim programı dizayn etmeleri gerektiğinin altını çizmiştir. Özellikle ortaokul seviyesindeki öğrenciler için iklim değişikliğine farkındalığı artırmak amacıyla böyle bir programa fazlasıyla ihtiyaç duyulmaktadır (Robinson, 2011; Alexandru vd., 2013).
İklim değişikliği eğitimi ve iklim okuryazarlığ gelişmekte olan bir alan olduğundan dünyada olduğu gibi ülkemizde de bu konuyla ilgili yapılan karşılaştırmalı eğitim araştırmaları sınırlıdır. Çoğunlukla çevre eğitimi (Bodlalo, Sabbaghan ve Jome, 2013; Derman, 2015; Yolcu, 2014; Özata vd., 2013) ve çevre okuryazarlığı (Erdoğan, Kostova ve Marcinkowski, 2009; Srbinovski, Erdogan ve Ismaili, 2010), kısmen de sürdürülebilir kalkınma eğitimi (Huai-xin ve Dillon, 2001; Bagoly-Simó, 2013; Bamber vd., 2016; Kaya ve Tomal, 2011) ve iklim okuryazarlı̆̆ (Yakar ve Karakuş, 2019) ile ilgili karşılaştırmalı eğitim çalışmalarına rastlanılmaktadır. Bagoly-Simó (2013), Sürdürülebilir kalkınma eğitimi ile ilişkili 46 konu başlı̆̆ belirleyerek Meksika, Romanya ve Almanya (Bavyera)'da ortaokul kademesi öğretim programlarını sürdürülebilir kalkınma eğitimi yaklaşımına göre incelemiştir. Bu başlıklardan biri de iklim değişikliğidir. Elde edilen bulgulara göre Almanya (Bavyera)'da sürdürülebilir kalkınma ile ilgili iklim değiş̧ikliği konularına daha fazla yer verildiğini tespit etmiştir. Chang ve Pascua (2017), iklim değiş̧ikliği eğitimi ile ilgili çeşitli çalışmaları incelemiş, Singapur'da iklim değişikliği eğitimi yaklaşımının tersine disipliner yaklaşımın, Filipinler'de ise iklim değişikliği eğitimi yaklaşımına uygun olarak disiplinlerarası yaklaşımının öne çıktığını vurgulamışlardır. Yakar ve Karakuş (2019), Türkiye sosyal bilgiler öğretim programlarını 1968-2018 yılları arasını temel alarak iklim okuryazarlığı ilkeleri açısından incelemişlerdir. Çalışmada 2005 Sosyal Bilgiler öğretim programı kazanımları ile iklim okuyazarlığının ilkeleri ilişkilendirilmiştir. Elde edilen bulgulara göre 4., 5., 6. ve 7. sınıfta iklim okuryazarlığı ilkelerini kapsayan kazanımların yer aldığ 1 tespit edilmiştir. Özkaral (2019), Türkiye, Kanada (Ontario) ve Hong Kong sosyal bilgiler öğretim programlarında küresel ısınma ve iklim değişikliği konusunu karşılaştırmıştır. Elde edilen bulgularda karşılaştırılan ülkelere göre Türkiye sosyal bilgiler öğretim programında iklim değiş̧ikliği konusuna daha az yer verildiğini tespit etmiştir.

Birçok ülke BM'nin çağrısına uyarak ve UNESCO'nun hükümetlere yardımıyla müfredatlarını İklim Değişikliği Eğitimi yaklaşımına uygun olarak şekillendirmektedir. Bu çalışmanın amacı da PISA (Uluslararası Öğrenci Değerlendirme Programı) 2015 sonuçlarına göre yüksek puan elde eden ülkelerin ortaokul kademesi öğretim programlarını iklim değişikliği eğitimi yaklaşımına göre disiplin farkı gözetmeksizin karşılaştırmalı olarak incelemektir. Öğrencilerin değişen ve gelişen dünyada iklim değişikliğini azaltım ve iklim değişikliğine uyum sürecine olumlu katk1 sağlayabilecek beceriler geliştirmesi, hem günümüzde hem de gelecekte yaşanabilecek çevresel sorunlara karşı toplumun ihtiyaç duyduğu farkındalıklarını artırabilmesi 
amacıyla iklim değişikliği eğitimi yaklaşımına dayalı öğretim programları geliştirmek önemlidir. PISA 2015 sonuçlarına göre yüksek puan elde eden ülkelerin ortaokul kademesi öğretim programlarını iklim değişikliği eğitimi yaklaşımına göre ülkemiz ortaokul öğretim programları ile karşılaştıran bu çalışma, ülkemizdeki iklim değişikliği eğitimi hakkında bir durum tespiti yapma ve iklim değişikliği eğitimi yaklaşımına dayalı öğretim programı geliştirecek araştırmacılara öncülük ve rehberlik etme amacı taşımaktadır.

\section{YÖNTEM}

Araştırmada elde edilen veriler doküman incelemesi yöntemi kullanılarak Karşılaştırmalı Eğitimin tanımlayıcı yaklaşımına göre analiz edilmiştir. Yıldırım ve Şimşek (2013)'e göre "Doküman incelemesi, araştırılması hedeflenen olgu veya olgular hakkında bilgi içeren yazılı materyallerin analizini kapsar. Doküman incelemesi tek başına bir yöntem olabileceği gibi diğer veri toplama yöntemleri ile birlikte de kullanılabilir."

Araştırmada öğretim programları incelenecek ülkelerin belirlenmesinde Uluslararası Öğrenci Değerlendirme Programı (PISA) 2015 yılı Matematik okuryazarlığı, Fen Bilimleri okuryazarlığı ve Okuma Becerileri puanları temel alınmıştır. 2015 PISA sonuçlarına göre Finlandiya, İsveç, İspanya, Kanada, Avustralya, İngiltere, Almanya, Amerika Birleşik Devletleri (ABD), Güney Afrika Cumhuriyeti ve Türkiye'de İklim, İklim Değişikliği, Küresel Isınma konularını içeren ortaokul düzeyi öğretim programları incelenmiştir. Güney Afrika Cumhuriyeti 2015 PISA'ya katılmamasına rağmen iklim değişikliğinden en çok etkilenen kıtada yer alması sebebiyle öğretim programları incelenecek ülkelere eklenmiştir. Öğretim programlarının incelemesi için belirlenen ülkelerden Kanada, Avustralya, Almanya, İspanya ve ABD'nin ulusal eğitim programı olamamasından dolayı 2015 PISA sonuçlarına göre en başarılı eyaletlerin öğretim programları incelenmek üzere seçilmiştir. Bu eyaletler: Kanada'da British Columbia, Avustralya'da Western Australia, İspanya'da Castilla Leon Özerk Bölgesi, Almanya'da Bavyera ve ABD'de Massachusetts Eyaleti'dir. Türkiye dahil olmak üzere araştırma kapsamındaki ülkelerin bir kısmı 2015 yılından sonra ortaokul öğretim programlarını güncellemiş̧tir. Fakat bu araştırma 2015 yılı PISA sonuçlarını temel aldığı için güncel müfredatlar çalışmaya dahil edilmemiştir.

Finlandiya, İsveç, İspanya (Castilla Leon Özerk Bölgesi), Kanada (British Columbia Eyaleti), Avustralya (Western Australia Eyaleti), İngiltere, Almanya (Bavyera Eyaleti), Amerika Birleşik Devletleri (Massachusetts Eyaleti), Güney
Afrika Cumhuriyeti ve Türkiye ortaokul kademesi öğretim programları disiplin farkı gözetmeksizin İklim Değişikliği Eğitimi Yaklaşımına göre hedef ve kazanım bilgisi boyutunda karşılaştırmalı olarak incelenmiş ve yorumlanmıştır.

İklim Değişikliği Eğitimi son y1llarda kendi kimliğini oluşturmaya başlamış bir yaklaşım olduğundan standart bir eğitim anlayışından söz etmek mümkün değildir. Fakat giriş bölümünde de belirtildiği üzere İklim Değişikliği Eğitimi’nin bileşenleri ve İklim Okuryazarlığı'nın ilkeleri arasında benzerlikler bulunmaktadır. Araştırma kapsamındaki ülkelerin öğretim programları bu bileşen ve ilkeler doğrultusunda incelendikten sonra bulguların analizine geçilmiştir.

\section{BULGULAR}

Giriş Bölümünde de söz edildiği gibi İklim Değişikliği Eğitimi yaklaşımına uygun olarak iklim ve iklim değişikliği konularını içeren dersler disiplinlerarası olarak verilmelidir. İklim ve İklim Değişikliği ile ilgili Hedef-kazanımlar öğrencilerde kavram yanılgılarına neden olmayacak biçimde düzenlenmelidir. Bunun için de İklim Değişikliği ile ilgili kavramların ardışık, sıralı, ilişkili, birbirini izleyen, önkoşul öğrenme birimlerinin olduğu, konuların yakından uzağa, bilinenden bilinmeyene, basitten karmaşı̆̆a, somuttan soyuta doğru örüntülenmesi gerekmektedir. İklim değişikliğinin süreç ile ilişkisini öğretebilmek için öğrenciye yaparak-yaşayarak öğrenme faaliyetleri sunulmalıdır. İklim Değişikliğinin etkileri yerel ve bölgesel olaylarla ilişkilendirilmeli, kaynakların sürdürülebilir kullanımını içermeli, iklim değişikliği eğitimi yaklaşımına uygun pedagojiler ve etkili materyaller içermelidir.

\subsection{Türkiye Ortaokul Öğretim Programlarında İklim Değişikliği Eğitimi}

Türkiye'de ortaokul kademesi ilköğretimin ikinci kademesini kapsayan 5., 6., 7. ve 8. sınıfları içermektedir. Türkiye ulusal müfredatında ortaokul kademesinde iklim ve iklim değişikliği ile ilgili konular 5., 6. ve 7. sinıflarda Sosyal Bilgiler dersinde, 5., 6., 7. ve 8. siniflarda Fen ve Teknoloji dersinde iklim değişikliği eğitimine uygun olarak disiplinlerarası bir yaklaşımla verilmektedir (Milli Eğitim Bakanlığı, 2004, 2013).

İklim değişikliği eğitiminin bileşenlerinden biri olan iklim değişikliğini yerel unsurlarla bütünleştirme ilkesinin ülkemiz müfredatında yüzeysel olarak verildiği söylenebilir. Örneğin 5 . Sınıf Sosyal Bilgiler müfredatında verilen "Yaşadı̆̆ bölgede görülen bir afet ile bölgenin coğrafì özelliklerini ilişkilendirir" 
ve "Yaşadiğı bölgede görülen doğal afetlerin zararlarını artıran insan faaliyetlerini fark eder" kazanımlarında öğrenci, bulunduğu bölgede görülen bir afet ile yine bulunduğu bölgenin coğrafi özelliklerini bütünleştirmekte, doğal afetlerin zararlarını artıran insan faaliyetlerini irdelemekte; fakat iklim değişikliğinden bahsedilmemektedir. Yine "Yaşadığ bölgedeki ekonomik faaliyetler ile coğrafï özellikleri ilişkilendirir" ve "Yaşadığı bölgedeki ekonomik faaliyetlerin ülke ekonomisindeki yerini değerlendirir" kazanımlarında öğrenci bulunduğu bölgenin ekonomik olanaklarıla coğrafi şartları ilişkilendirmekte, bu ekonomik faaliyetlerin ülke ekonomisindeki yerine değinilmekte; fakat Sürdürülebilir Kalkınma İçin İklim Değişikliği Eğitimi yaklaşımının gerektirdiği sürdürülebilirlik kavramı öğrenciye verilmemektedir. NOAA'nın (US GCRP, 2009) belirlediği iklim sisteminin temel ilkelerinden biri olan "Dünya üzerindeki yaşam iklime bağlıdır, iklim tarafından şekillenir ve iklimi etkiler" ilkesinin, "Yaşadı̆̆ı bölgede görülen iklimin, insan faaliyetlerine etkisini, günlük yaşantısindan örnekler vererek açıklar” kazanımı ile verildiği söylenebilir.

6. Sınıf Sosyal Bilgiler müfredatında ise "Ülkemizin kaynaklarıyla ekonomik faaliyetlerini ilişkilendirerek, bunların ülke ekonomisindeki yerini ve önemini değerlendirir" kazanımı ile öğrenci, 5. Sınıfta yerel ve bölgesel açıdan değerlendirdiği ekonomik faaliyetler ile coğrafi şartlar arasındaki ilişkiyi ülke genelinde değerlendirmekte fakat yine sürdürülebilirlik kavramı öğrenciye verilmemektedir. Yine 6. Sinıf Sosyal Bilgiler müfredatında "Doğal kaynakların bilinçsizce tüketilmesinin insan yaşamına etkilerini tartışı" "kazanımında öğrenciye doğal kaynakların bilinçsizce tüketilmesinin insan yaşamına etkisi öğretilmekte fakat iklim değişikliği ile bağlantısı göz ardı edilmektedir.

İklim değişikliği eğitimi yaklaşımının en önemli bileşenlerinden biri öğrencilerde kavram yanılgılarının oluşmasını engelleyebilmektir. İklim değişikliği üzerine yapılan deneysel çalışmalara göre öğrencilerde en çok gözlenen kavram yanılgıları: "küresel 1sınmanın nedenleri ve iklim değişikliği, sera gazı ve sera etkisi, küresel ısınma ve iklim değişikliği, iklim ve hava durumu, karbon döngüsü ve sera etkisi, küresel 1sınmanın ve iklim değişikliğinin etkileridir" (Shepardson vd., 2012). Ülkemiz müfredatında ise küresel ısınma ve iklim değişikliğine kısmen değinildiği söylenebilir. Örneğin 7. Sınıf Sosyal Bilgiler müfredatında "Küresel sorunlarla uluslararası kuruluşların kuruluş amaçlarını iliş̧kilendirir" ve "Küresel sorunların çözümlerinin yaşama geçirilmesinde kişisel sorumluluğunu fark eder" kazanımlarında iklim değişikliği ve küresel ısınma yüzeysel olarak ele alınmaktadır.
İklim değişikliği eğitimi yaklaşımının amacı iklim okuryazarı bireyler yetiştirmektir. İklim okuryazarı, iklim sisteminin temel ilkelerini anlayan, iklim hakkında bilimsel olarak güvenilir bilgiyi nasıl değerlendireceğini bilen, iklim değişikliğinin etkilerini en aza indirebilecek bilinçli kararlar alabilen ve sürdürülebilir toplumların sağlanmasına yardımcı olacak şekilde hareket eden çevresel tutum ve davranışları gelişmiş bir bireydir (UNESCO, 2009a; Mochizuki ve Bryan, 2015; UNESCO, 2015). Ülkemiz ortaokul müfredatında iklim okuryazarlığını oluşturan bileşenlerden "iklim sisteminin temel ilkeleri" öğrencilere iklim değişikliği ile bağlantısı kurulmadan verilmektedir. İklim sisteminin temel ilkeleri: "Güneşin, Dünya'nın iklim sistemi için temel enerji kaynağı olduğu; iklimin, Dünya sisteminin bileşenleri arasındaki karmaşık etkileşimlerle düzenlendiği; Dünya üzerindeki yaşamın iklime bağll olarak şekillendiği ve iklimi etkilediği; iklimin doğal ve beşeri süreçler vasitasıyla zaman ve mekan üzerinde değiştiği, iklim sistemine ilişkin anlayışımızın gözlem, teorik çalışmalar ve modelleme yoluyla geliştirildiği; insan faaliyetlerinin iklim sistemini etkilediği; iklim değişikliğinin hem Dünya üzerinde hem de insan yaşamı üzerinde sonuçları olacağı" bilgisini içerir (US GCRP, 2009). Bu temel ilkeler çerçevesinde ülkemiz Fen ve Teknoloji dersi 8. sınıf müfredatında "Yakın çevresindeki hava olaylarını gözlemler, sonuçları kaydederek hava olaylarının değişkenliğini fark eder", "Hava olaylarının sebebini günlük sıcaklık farklllıkları ve oluşan alçak ve yüksek basinç alanlarıyla açılklar", "Yeryüzü şekillerinin oluşumu ve değişiminde hava olaylarının etkisini örneklerle açıklar", "İklimin, yeryüzünün herhangi bir yerinde uzun ylllar boyunca gözlenen tüm hava olaylarınin ortalama durumu olduğunu ifade eder ve iklimlerin zamanla değişebileceğini kavrar" kazanımları ile iklim sisteminin temel ilkelerinden "iklim doğal ve beşeri süreçler vasitasiyla zaman ve mekân üzerinde değişir" ilkesi ortaya konmakta fakat iklim değiş̧ikliği ile ilişkisi öğrencilere verilmemektedir. Shepardson vd., (2012) öğrencilerin ders etkinliği olarak yerel hava durumu verileri toplayabileceklerini ve bu verileri yerel iklim ile ilişkilendirebileceklerini belirtmiş ancak zaman ve ölçek sorunlarından dolayı iklim değişikliğini izleyemeyeceklerini ifade etmiştir. Bu yüzden öğrencilerin iklim ve değişim kavramları arasında gözlemleyerek bağlantılar kurması zordur. İklim ve değişim arasındaki bağlantılar kasıtlı olarak öğretilmelidir (McKeown ve Hopkins, 2010).

\subsection{Finlandiya Ortaokul Öğretim Programlarında İklim Değişikliği Eğitimi}

Finlandiya'da ortaokul kademesi 7., 8. ve 9. sinifları kapsamaktadır. Finlandiya ulusal ortaokul müfredatında iklim ve 
iklim değişikliği ile ilgili konular bazı derslerde iklim değişikliği eğitimi yaklaşımına uygun olarak disiplinlerarası bir yaklaşımla verilirken, bazı derslerde ise Türkiye ortaokul öğretim programlarından farklı olarak iklim değişikliği eğitimi yaklaşımının tersine disipliner bir yaklaşımla verilmektedir. İklim ve iklim değişikliği ile ilgili konular Sosyal Bilgiler dersinde disiplinlerarası bir yaklaşımla verilirken, Coğrafya ve Biyoloji derslerinde disipliner bir yaklaşımla verilmektedir (Finnish National Board Of Education, 2004). Sosyal bilgiler dersinde öğrencilere sürdürülebilir kalkınma bağlamında bilinçli tüketici kavramı aşılanırken iklim ve iklim değişikliği ile ilgili kazanımlara coğrafya ve biyoloji derslerinde rastlanılmaktadır. Coğrafya dersi iklim değişikliği eğitimi yaklaşımının tersine disipliner bir yaklaşımla verilmesine rağmen; içerikte iklim değişikliği eğitimi yaklaşımına uygun olarak doğa bilimleri ve sosyal bilimlerin birbirine entegre biçimde öğrencilere aktarıldığ görülmüştür. "Asya, Kuzey ve Güney Amerika, Avustralya ve Avrupa olmak üzere iki veya daha fazla kıtanın doğal koşulları ile insan faaliyetlerini karşılaştırır”, "Avrupa'nın doğal koşulları ile insan faaliyetlerinin, Avrupa 'nın farklı bölgeleri ile etkileşimini inceler", "Finlandiya'nın farkll bölgelerinde doğa koşullarını, insan faaliyetlerini ve yapay çevreyi inceler", "Baltık bölgesindeki çevre sorunlarını inceler", "Finlandiya'nın doğal ve yapay çevreleri ile kendi bölgesel kimliğini algılar", "Asya, Kuzey ve Güney Amerika, Avustralya ve Avrupa olmak üzere iki veya daha fazla kitanın doğal koşullar ile insan faaliyetlerini karşılaştırır" kazanımlarında görüldüğü üzere konular iklim değişikliği eğitimi yaklaşımına uygun olarak; yerel ve bölgesel unsurlarla ilişkilendirilmekte ve kitasal karşılaştırmalar yapılmaktadır. Öğrencilerin bölgesel kimliğini anlamaya yönelik kazanımların yanı sıra "Yerel ve küresel çevre sorunlarına olası çözüm önerileri getirir”, "Baltık bölgesinin çevre sorunlarını ve nedenlerini betimleyerek bölgenin çevresel durumunu iyileştirme konusunda öneriler sunar" "Kendi bölgelerindeki doğal ve yapay çevre hakkında küçük çaplı çalışmalar planlar", "Küresel çevre ve kalkınma sorunları gibi konularda medya haberlerini eleştirel olarak değerlendirir ve sürdürülebilir kalknnmaya uygun olarak hareket eder" gibi Türkiye ortaokul öğretim programlarından farklı olarak üst düzey düşünme becerilerini geliştirmeye yönelik kazanımların da mevcut olduğu söylenebilir. "Küresel çevre ve kalkinma sorunlarının (sera etkisi, çölleşme, çevre kirliliği) neler olduğunu kısaca açıklar", "Çevrenin durumunun iyileştirilmesine katkıda bulunmak için neler yapabileceğini tanımlayarak, küresel çevre ve kalkınma sorunlarının çözüm yollarını bilir", "Çevreyi korumanın temel amaçlarını ve doğal kaynakların sürdürülebilir tüketim ilkelerini anlar" kazanımlarında İklim ve iklim değişikliği ile ilgili konuların Sürdürülebilir Kalkınma için İklim
Değişikliği Eğitimi yaklaşımı temel alınarak öğrencilere aktarıldığı ve öğrencilerin sürdürülebilirlik konusunda aktif rol almaları için güdülendikleri ifade edilebilir. Görüldüğü gibi, Finlandiya ulusal müfredatı ortaokul öğretim programlarında iklim ve iklim değişikliği ile ilgili hedeflerde bölgesel ve kıtasal karşılaştırmalarla insan faaliyetlerinin etkisi, sürdürülebilir kalkınma, yerel çevre sorunları gibi iklim ve iklim değişikliği ile ilgili önemli konulara iklim değişikliği yaklaşımına uygun olarak vurgu yapılmaktadır.

\subsection{Almanya Ortaokul Öğretim Programlarında İklim} Değişikliği Eğitimi

Almanya'nın Bavyera Eyaletinde ortaokul kademesi 5., 6., 7., 8. ve 9. sınıfı kapsamaktadır. İklim ve iklim değişikliği ile ilgili konular 5., 6. ve 7. sınıflarda Doğa ve Teknoloji dersinde iklim değişikliği eğitimi yaklaşımına uygun olarak disiplinlerarası yaklaşımla verilirken 5., 7. ve 8. sınıflarda Coğrafya, 8. ve 9 . sınıflarda Biyoloji derslerinde disipliner yaklaşımla verilmektedir (Staatsinstitut für Schulqualität und Bildungsforschung München, 2009). İklim ve iklim değiş̧ikliği ile ilgili konular Sürdürülebilir Kalkınma için İklim Değişikliği Eğitimi yaklaşımı temel alınarak öğrencilere aktarılmaktadır. Örneğin “Ekonomik ve ekolojik açıdan basit örneklerle biyolojik çeşitliliği ve sürdürülebilir kalkınmayı karşılaştırır", "Sürdürülebilir kalkınmaya katkl olarak kentlerin yeniden yapılandırılması konusunda değerlendirmelerde bulunur", "Gelişmekte olan ülkelerin sorunlarını ifade ederek kalkınma işbirliğine duyulan gereksinimi örneklerle açılklar", "Farklı kalkınma düzeylerini değerlendirir", "Kaynakların sürdürülebilir kullanımı için öneriler sunar", "Somut kalkınma projelerine sınıfça katılım yollarını tartışır”, "İnsanın doğaya müdahalesini açıklayarak sürdürülebilir kalkınma bağlamında yapılabilecek bireysel eylemleri tartışır", "Yerel bir ekosisteme insan müdahalesi sonucunda tarım, ormancllı, kentleşme konularında oluşan sorunlart tartışır ve sürdürülebilir yöntemleri değerlendirir”, "Sürdürülebilir gıda üretimi için toprağın önemini değerlendirir", "Afrika'daki ekosistemleri doğal ve beşeri faktörlere göre değerlendirerek sürdürülebilir kullanım yöntemlerini tartışı"” kazanımlarında İklim ve iklim değişikliği ile ilgili konuların Türkiye ortaokul öğretim programlarından farklı olarak üst düzey düşünme becerilerini geliştirmeye yönelik olduğu ve Sürdürülebilir Kalkınma için İklim Değişikliği Eğitimi yaklaşımı temel alınarak öğrencilere aktarıldığı söylenebilir. Bavyera ve Almanya'daki doğal afetlere karşı önlemler alır", “Avrupa'nın iklim ve bitki örtüsünün özelliklerini tanımlar” gibi kazanımlarda görüldüğü üzere konular iklim değişikliği eğitimi yaklaşımına uygun olarak; yerel ve bölgesel unsurlarla 
ilişkilendirilmektedir "Hava unsurları ile ilgili basit ölçümler yapar ve elde edilen verileri diyagramlara dönüştürür", "İklim diyagramların analiz ederek değerlendirir ve verileri iklim tablolarından iklim haritalarına dönüştürür", "İklim ve bitki örtüsü ile ilgili hava fotoğraflart ve uydu görüntülerini değerlendirir" gibi kazanımlarda görüldüğü üzere “UNESCO'nun önerdiği öğretme - öğrenme stratejileri ile özellikle tartı̧̧ma ve fikir yürütme, proje tasarlama gibi etkinliklerin yanı sıra coğrafi bilgi sistemleri de kullanılmaktadır.

\subsection{ABD (Massachusetts) Ortaokul Öğretim Programlarında İklim Değişikliği Eğitimi}

ABD Massachusetts eyaletinde ortaokul 6., 7. ve 8. sinifları kapsamaktadır. İklim ve iklim değişikliği ile ilgili konular hem Tarih ve Sosyal Bilimler (History and Social Science) dersinde hem de Fen ve Teknoloji (Science and Technology / Engineering) dersinde disiplinlerarası bir yaklaşımla verilmektedir (Massachusetts Department of Elementary and Secondary Education, 2006). Fakat iklim değişikliği eğitimi yaklaşımında öne çıkan yerel unsurlarla iklim ve iklim değişikliğini bütünleştirebilme ilkesi Massachusetts eyaletinde kıtasal karşılaştırmalarla yapılmaktadır. Öğrenciler Tarih ve Sosyal Bilimler dersinde her bir ünitede ayrı bir kıtayı bir bütün olarak tarihsel gelişiminden iklim özelliklerine kadar incelemektedir. Örneğin "Kuraklık ve çölleşmenin Afrika'nın bazı bölümlerini nasıl etkilediği”, "Bazı bölgelerdeki su kıtlı̆̆ını telafi etmek için kullanılan yöntemler”, "Doğu Avrupa'nın eski uydu ülkelerinde, bir zamanlar Sovyetler Birliği’nin bir bölümünde bulunan ülkelerde ve Rusya'da hava, su ve topraklardaki büyük kirlilik kaynakları ve etkileri", "Dünyayı şekillendiren ve sonunda insanoğlunun yayılmasına, gelişmesine neden olan büyük iklimsel ve çevresel değişiklikler" gibi. Fen ve Teknoloji dersinde ise iklim değişikliğinin lise eğitimine kadar müfredatta tam olarak yer almadığı söylenebilir. Fen ve Teknoloji dersinde iklim ve iklim değişikliği ile ilgili çoğunlukla kaynakların sürdürülebilir kullanımına ilişkin ifadelerin yer aldığı, öğrencilerden beklenen beceriler kapsamında "Insan faaliyetlerinin ve teknolojilerin doğal kaynakların kişi başına tüketimini ve insan popülasyonundaki artışların etkisini azaltabileceğì" ile ilgili yapıcı örnekler vermesinin beklendiği ifade edilebilir. Yine Fen ve Teknoloji dersinde öğrencilerden "Güneş'ten gelen enerji girdileri aracılı̆̆ıyla okyanus isısındaki değişimi ve okyanus akıntılarl yoluyla buharlaşmadan kaynaklanan enerji kaybinın bölgesel ölçekte hava ve iklimi nasıl etkilediğini" "Geçtiğimiz yüzyılda küresel sicaklıklarda yükselmeye neden olarak insan faaliyetlerinin oynadiğı rolü” açıklamaları ve bu açıklamayı yaparken "Insan faaliyetlerine örnek olarak fosil yakıt kullanımını, ormansızlaşmayı ve tarımsal faaliyetleri örnek verebilmeleri" beklenmektedir.

Görüldüğü üzere $\mathrm{ABD}$ Massachusetts ortaokul öğretim programlarında iklim değişikliği eğitimi ile ilgili Türkiye ortaokul öğretim programlarından farklı olarak geçmiş dönem iklim değişikliklerinin insan yaşamı üzerindeki etkisinin ve geçtiğimiz yüzyılda küresel sıcaklıklarda yükselmeye neden olan insan faaliyetlerinin vurgulandığı söylenebilir.

\subsection{Avustralya (Western Australia) Ortaokul Öğretim} Programlarında İklim Değişikliği Eğitimi

Avustralya'nın Western Australia Eyaletinde ortaokul kademesi 7, 8, 9 ve 10. sınıfı kapsamaktadır. İklim ve iklim değişikliği ile ilgili konular Beşeri ve Sosyal Bilimler öğrenme alanı içerinde yer alan Coğrafya müfredatında disipliner bir yaklaşımla verilirken Fen Bilimleri öğrenme alanı içerinde yer alan Dünya ve Çevre Bilimleri (Earth and Environmental Science) müfredatında disiplinlerarası bir yaklaşımla verilmektedir (Government of Western Australia, 2015). Müfredat kapsamında iklim ve iklim değişikliği konuları öğretilirken iklim değişikliği eğitimi yaklaşımına uygun olarak yerel ve bölgesel unsurlarla ilişkilendirilmektedir. Örneğin "Avustralya'nın su kaynaklarının diğer kitalara klyasla miktarı ve değişsenliğini değerlendirir", “”Avustralya ve Batı Asya'dan ve / veya Kuzey Afrika'dan örnekler de dâhil olmak üzere su kıtlığının doğası ve çözümü için öneriler sunar", "Endonezya'da veya Asya bölgesinde ki bir ülkede yapılan bir araştırmaya dayanarak endüstrileșmenin nedenlerini inceler", "Avustralya ve dünya genelinde tarımda verimliliği etkileyen çevresel, ekonomik ve teknolojik faktörleri ifade eder", "Avustralya'da ve dünyanın diğer alanlarında toprak ve suyun bozulmasl, temiz su sıkıntısı, arazi kullanımında rekabet ve iklim değișikliği de dâhil olmak üzere gıda üretiminde karşılaşılan zorlukları ve sonuçlarını tartışır", "Sel ve yangin gibi afetlerin Avustralya'ya özgü tavşan veya kanguru popülasyonlarına etkisini değerlendirir" kazanımlarında görüldüğü üzere öğrenciler konuları yerel ve bölgesel unsurlarla ilişkilendirip kıtasal karşılaştırmalar da yapmaktadırlar. "Dünyanın gelecekte öngörülen küresel nüfusu sürdürülebilir şekilde besleyebilme kapasitesi", "Sürdürülebilirliği tehdit eden insan kaynakl çevresel değişiklikler”, “Avustralya'nın çeşitli bölgelerinde (araziler, ormanlar, çöller, otlak alanları, tarım arazileri, içsular, klyılar, deniz veya şehirler) çevre yönetimi yaklaşımları", "Avustralya ve bir başka ülkeden seçilmiş çevresel değişiklik örneklerinin karşılaştırmalı bir çalışması", "Kirlilik, hava kalitesi, su kalitesi, çevresel etki, sürdürülebilir kalkınma, 
sürdürülebilir tarlm, jeotermal enerji, güneş enerjisi, rüzgar gücü, hidroelektrik, fosil yakıtlar, biyoyakıtlar, atı yönetimi kavramlart", "Ormansızlaşma ve tarım ürünleri üzerinde insan faaliyetlerinin etkisi”, "Doğadaki su döngüsünü etkileyen faktörler", "Avustralyalı bilim insanlarının çevre üzerinde insan faaliyetlerinin etkisi ile ilgili katkı sağladikları yerel çevre yönetimi projeleri", "Sanayi, tartm ve deniz ürünleri ile ilgili kaynak yönetiminde insan faaliyetleri (atı maddelerin sinıflandırllması, kirliliğin azaltılması, petrol sizintılarının temizlenmesi gibi fiziksel ayırma tekniklerinin günlük uygulamalarını araştırma, bilim ve teknolojideki ilerlemelerin endüstriyel ve evsel sistemlerde suyun arittlmasinda nasıl uygulandı̆̆ın araştırma gibi...)”, “Arazi yönetimi uygulamalarının çevrenin sürdürülebilir yönetimine nasıl yardımcı olabileceğì", "Verimliliği ve sürdürülebilirliği artırmak için modern tarım tekniklerinin nasıl uygulandı̆̆gl " gibi konuların kaynakların sürdürülebilir kullanımı ilkesi temel alınarak öğrencilere aktarıldığı söylenebilir. "Sera etkisinin nedenleri ve etkileri”, "İklim değişikliğinin deniz seviyeleri ve biyoçeşitlilik üzerindeki etkisi", "Buzullardaki değişiklikler ve bu değişikliklerin etkileri", "Derin okyanus akıntılarını yönlendiren faktörler ve okyanus akıntılarının küresel iklim üzerindeki rolleri", "İklim değişikliğinin nedenleri", "Karbon kirliliğinin azaltılmasına ilişkin teknolojiler", "Atmosferdeki ozon tabakasinı etkileyen Kloroflorokarbonlar" gibi konular ile öğrencilerin iklim değişikliği eğitiminde en çok karşılaşılan "küresel ısınmanin nedenleri ve iklim değişikliği, sera gazı ve sera etkisi, küresel ısınma ve iklim değişikliği, iklim ve hava durumu, karbon döngüsü ve sera etkisi, küresel ısinmanin ve iklim değişikliğinin etkileri" gibi kavram yanılgılarından iklim sistemini daha sistematik öğrenerek kaçındıkları ifade edilebilir.

\subsection{Güney Afrika Cumhuriyeti Ortaokul Öğretim Programlarında İklim Değişikliği Eğitimi}

Güney Afrika Cumhuriyeti ortaokul aşaması 7., 8. ve 9. sınıfları kapsamaktadır. İklim ve iklim değişikliği ile ilgili konular Sosyal Bilimler dersi ile Doğa Bilimleri derslerinde disiplinlerarası bir yaklaşımla verilmektedir (Department of Basic Education Republic of South Africa, 2011). İklim ve iklim değişikliği ile ilgili konular "Afrika kıtasından seçilmiş bir taşkın olayını inceler", "Afrika kıtasından seçilmiş bir sulak alanda yaşanan çevresel problemleri inceler", "Güney Afrika'da erozyon vakalarını inceleyerek tarım, inşaat, madencilik yoluyla erozyon oluşumunda insanın rolünü tartışır" kazanımlarında görüldüğü üzere yerel ve bölgesel unsurlarla ilişkilendirilmekte fakat araştırma kapsamında yer alan birçok ülkede görülenin aksine kıtasal karşılaştırmalara yer verilmemektedir.
"Sürdürülebilir kalkınmada ekonomik, sosyal ve çevresel faktörleri değerlendirir", "Yenilenebilir ve yenilenemez doğal kaynakların kullanımı ile bilinçsiz kaynak kullanımının etkilerini değerlendirir", "Okyanuslarda aşırı balık avlamanın ve aşırı otlatmanın etkilerini tartışır", "Kaynakların sürdürülebilir kullanımı kapsamında sürdürülebilir ve sürdürülemez kaynak kullanımı kavramlarını tanımlar", "Kaynakları sürdürülebilir şekilde kullanmak için öneriler getirir", "Sürdürülebilir balıkçılık faaliyetleri ve otlatma için sürdürülebilir arazi kullanımı ile ilgili öneriler sunar", "Tüketicilerin, işletmelerin ve hükümetlerin kaynak kullanımı üzerindeki baskısını ve karbon ayak izini azaltmak için öneriler sunar" kazanımlarında Sürdürülebilir Kalkınma için İklim Değişikliği Eğitimi yaklaşımının temel alındığı söylenebilir. "Su, Çevre ve Turizm Genel Müdürlüklerinin web sitelerinde güncellenmis verileri ve raporlarl inceler", "Uydu görüntüleri aracılığıyla göllerin, bitki örtüsünün ve arazi kullanımlarının zamanla değişimini değerlendirir”, " Güney Afrika Cumhuriyeti'nin bazı bölgelerinin sicaklık verilerini elde ederek meteorolojik analiz yapar ve sıcaklık verilerini karşılaştırır" gibi kazanımlarda iklim değişikliği eğitiminin bileşenlerinden yaparak-yaşayarak öğrenme faaliyetlerinin de kullanıldığı ifade edilebilir. Türkiye ortaokul öğretim programlarından farklı olarak "Hava durumu ve iklim arasindaki farkı ayırt eder", "Atmosferin tüm bileşenlerini, Atmosfer katmanlarinı özellikle Troposfer, Stratosfer, Mezosfer ve Termosfer katmanlarını tüm özellikleri ile ögrenerek Stratosfer katmanının ozon gazı (O3) içerdiğini ve çok fazla ultraviyole ışınımın Dünya üzerindeki yaşamı tehdit ettiğini bilir" gibi kazanımlarda Atmosfer ve katmanları ile ilgili daha keskin ifadelerin yer aldığı söylenebilir. "Sera etkisini, sera etkisinin doğal bir fenomen olduğu ve sera gazlarındaki artışın küresel ısınmaya neden olduğunu, küresel ısınmanın atmosferin ortalama sıcaklıklarındaki bir artış olduğunu, küresel ısınmanın iklim değişikliğine, deniz seviyesinin yükselmesine, kutlığa ve kitlesel yok oluşlara yol açabileceğini bilir" gibi kazanımlar ile özellikle iklim değişikliği eğitiminde karşılaşılan kavram yanılgılarından sera etkisi, küresel ısınma ve iklim değişikliği arasındaki farkın sistematik bir biçimde öğrenciye aktarıldığı ifade edilebilir.

\section{7. İngiltere Ortaokul Öğretim Programlarında İklim Değişikliği Eğitimi}

İngiltere ulusal müfredatında iklim ve iklim değişikliği ile ilgili konular 7., 8. ve 9. sınıfı kapsayan ortaokulda Coğrafya dersinde iklim değişikliği eğitimi yaklaşımının tersine disipliner bir yaklaşımla verilirken, Fen Bilimleri dersinde ise iklim değişikliği eğitimi yaklaşımına uygun olarak disiplinlerarası bir 
yaklaşımla verilmektedir (Department for Education of United Kingdom, 2013). "Jeolojik devirlerden bu yana doğal kaynakların kullanımını yorumlar”, “Dünyanın sinırlı kaynaklara sahip olduğunu bilir ve geri dönüşümün önemini kavrar" kazanımlarında görüldüğü üzere İklim değiş̧ikliği eğitimi yaklaşımının bileşenlerinden kaynakların sürdürülebilir kullanımı müfredatta kısmen yer almaktadır. İklim değişikliğinin öğretimini zor kılan geçmiş dönem iklim değişikliklerini öğretebilmek iklim değişikliği yaklaşımında öne çıkan bir hususken Türkiye ortaokul ögretim programından farklı olarak İngiltere müfredatında "Buzul çağından günümüze kadar yaşanan iklim değişikliklerini yorumlar", "Insanların ve fiziksel süreçlerin iklimi nasll etkilediğini, değiştirdiğini ve insan faaliyetlerinin doğal sistemlerin işleyişini nasll etkilediğini tartışır" kazanımları buzul çağından günümüze kadar yaşanan iklim değişikliklerine yer verildiği söylenebilir. "Tematik haritaları, hava ve uydu fotoğraflarını yorumlar", "Coğrafi Bilgi Sistemlerini (CBS) kullanarak verileri analiz eder ve yorumlar", "Coğrafi verileri toplar, analiz eder ve saha çalı̧̧masl yapar" gibi kazanımlar ile yine Türkiye ortaokul öğretim programından farklı olarak UNESCO'nun önerdiği öğretme - öğrenme stratejilerinden faydalanıldığ 1 ifade edilebilir.

\section{8. İspanya (Castilla ve León Özerk Bölgesi) Ortaokul Öğretim Programlarında İklim Değiş̧ikliği Eğitimi}

İspanya'da Kastilya ve León Özerk Bölgesi'nde ortaokul aşaması 7., 8., 9. ve 10. sınıfları kapsamaktadır. İklim ve iklim değiş̧ikliği ile ilgili konular Sosyal Bilimler, Coğrafya ve Tarih (Ciencias sociales, Geografía e Historia) dersi ile Doğa Bilimleri (Ciencias de la Naturaleza) derslerinde iklim değişikliği eğitimine uygun olarak disiplinlerarası bir yaklaşımla verilmektedir (Ministeri D’educació I Ciència \&,Munidad Junta de Castilla y León, 2007).

Müfredat çerçevesinde yer alan iklim değişikliği ile ilgili konuların (biyoçeşitlilik ve sürdürülebilir kalkınma, doğa ve kalkınma arasındaki iliş̧kiler, sürdürülebilirlik politikaları, günümüzde insanliğın karşılaştı̆̆ sorunlara dikkat göstererek sürdürülebilir bir gelecek inşa etme, doğal kaynakların tanımlanması ve sinıflandırılmasi, su kaynaklarının kullanımı ve sürdürülebilir yönetiminin önemi, atık yönetimi, bilimsel ve teknik gelişimin sürdürülebilirliğe katkısı, temiz enerji kaynakları ve doğal kaynakların akalcr yönetimi” Sürdürülebilir Kalkınma için İklim Değişikliği Eğitimi yaklaşımı temel alınarak öğrencilere aktarıldığı söylenebilir. İspanya'nın tarımsal sorunları ve İspanya ekonomisinin önemli bir parçası olan balıkçılık faaliyetlerinde yaşanan sorunlar ile kaynakların sürdürülebilir kullanımı arasında ilişki kurularak öğrencilerin sürdürülebilirlik üzerine yaratıcı bir bakış açısı kazanmaları hedeflenmektedir.

"Küresel ve yerel ölçekte, çevre ile ilgili sorunlartn farkına vararak nedenlerini ve etkilerini açıklar", "Ispanya'da tarım ve balıkçlllk faaliyetlerini değerlendirir", "Avrupa ve İspanya'da insan faaliyetlerinin çevresel etkilerini tanımlayarak çevrenin korunmasına karşı alacağı önlemleri bilir", "İspanyol tarımının sorunlarını analiz eder", "Çevrenin bozulmasını önlemek ve doğal kaynakların korunması için bireysel eylemleri tartışır (Castilla ve León özerk bölgesinde özel bir vaka inceleme)", "Castilla ve León özerk bölgesindeki mevcut çevre sorunlarını önlemek için alınacak tedbirleri ifade eder" gibi kazanımlarda görüldüğü üzere iklim değişikliği eğitimi yaklaşımına uygun olarak konuların yerel ve bölgesel unsurlarla ilişkilendirildiği söylenebilir. Yine müfredat çerçevesinde yer alan iklim değişikliği ile ilgili konuların (Atmosfer ve atmosferik olaylar, iklimi oluşturan faktörler, iklim değişikliğinin nedenleri ve sonuçlarl, mevsimler, Atmosfer, Atmosferin bileşimi ve özellikleri, Karbon Dioksit ve Ozon'un çevresel etkileri, Atmosferik olaylar, hava durumu ve iklim ayrımı, Castilla ve León özerk bölgesinde iklimi şekillendiren jeolojik özellikler, sera etkisi, asit yağmuru, ozon tabakasının tahribi, su ve toprak kirliliği, sera etkisinin artmasinin nedenleri ve önlemleri, iklim değişikliği) Türkiye ortaokul öğretim programlarından farklı olarak daha detaylı işlendiği ifade edilebilir. "Belgesellerden ve internetten insan faaliyetlerinin farkll ekosistemler üzerindeki etkisi (örneğin kirliliğin etkileri, çölleşme, ozon tabakasinın seyrelmesi, kaynakların tükenmesi gibi) hakkında bilgi toplar ve analiz eder" kazanımında görüldüğü üzere iklim değişikliği eğitimi yaklaşımının bileşenlerinden yaparakyaşayarak öğrenme faaliyetlerine yer verildiği de söylenebilir.

\section{9. İsveç Ortaokul Öğretim Programlarında İklim Değişikliği Eğitimi}

İsveç ulusal müfredatında iklim ve iklim değişikliği ile ilgili konular 7, 8 ve 9. sınıfı kapsayan Coğrafya dersinde ve kısmen Fizik ve Kimya derslerinde iklim değişikliği eğitimi yaklaşımının tersine disipliner bir yaklaşımla verilmektedir (The Swedish National Agency for Education, 2012). "Sürdürülebilir kalkınma bağlamında çevre ve kalkınma konuları ile ilgili çözümleri değerlendirir", "Insanların yerel ve küresel olarak enerji ve doğal kaynakları kullanmasını sürdürülebilir kalkınma açısından tartışır", "Metal, kağıt ve plastik geri dönüşümünde yapılan kimyasal işlemleri, içme suyu ve atık suyunun arıtılmasına yönelik işlemleri inceler" gibi kazanımlarda görüldüğü üzere kaynakların sınırlı kullanımının Sürdürülebilir Kalkınma için İklim Değişikliği Eğitimi yaklaşımına uygun olarak müfredatta 
yer aldığ1 söylenebilir. Araştırma kapsamında incelenen ülkelerden farklı olarak "İklim değişikliğinin insan, toplum ve çevre üzerinde dünyanın farkl yerlerinde olabilecek etkilerini tartışır", "Sera etkisini ve iklim değişikliğini açıklamak için fizikteki modelleri kullanır" gibi kazanımlarla iklim değişikliğinin dünyanın farklı yerlerinde farklı biçimlerde kendini göstereceği ifade edilirken aynı zamanda iklim modellemelerinin kullanıldığı da ifade edilebilir. "Uydu görüntüleri gibi haritalar, coğrafi bilgi sistemleri (CBS) ve coğrafi araçlar yardımıyla iklimi değerlendirir" kazanımında araştırma kapsamındaki ülkelerde de görüldüğü üzere Türkiye ortaokul öğretim programlarından farklı olarak coğrafi bilgi sistemlerinden yararlanıldığı söylenebilir.

\subsection{Kanada (British Columbia) Ortaokul Öğretim Programlarında İklim Değişikliği Eğitimi}

Kanada'nın British Columbia Eyaletinde ortaokul aşaması 7., 8., 9. ve 10. sınıfları kapsamaktadır. İklim ve iklim değişikliği ile ilgili konular Sosyal Bilgiler ve Fen Bilimleri derslerinde iklim değiş̧ikliği eğitimine uygun olarak disiplinlerarası bir yaklaşımla verilmektedir (Ministry of Education British Columbia, 2005). "Günümüz kurumlarından bazllarını ziyaret ederek atık programları hakkinda bilgi alır", "Kanada ve diğer ülkelerdeki sürdürülebilir kaynak kullanımını araştırarak karşılaştırır" "Yerli halkların belirli bir ekosistemde çevresel sürdürülebilirliği nasll etkilediğini tartışır” gibi kazanımlarda görüldüğü üzere iklim değişikliği yaklaşımının bileşenlerinden kaynakların sürdürülebilir kullanımının müfredatta yer aldığı söylenebilir. "İklim değişikliği, ozon tabakasının seyrelmesi, sera etkisi, kuraklık, sel, su kirliliği, toprak bozulması ve ormansızlaşmanın ekosistemde yer alan canlılar üzerindeki etkilerini tanımlar", "İnsan faaliyetlerinin iklimi nasıl etkilediğini tartışarak örneklendirir", "Okyanus akıntıları ile rüzgârların bölgesel iklimlere etkisini değerlendirir" gibi kazanımlarda ise iklim değişikliğinin temel kavramlarının yer aldığı ifade edilebilir. "Uydu görüntülerini kullanarak Kanada'da ki sucul alanlarin zamanla nasıl değiştiğini yorumlar" kazanımında görüldüğü üzere çevresel sorunlar iklim değişikliği eğitimin yaklaşımına göre yerel ve bölgesel unsurlarla ilişkilendirilirken Türkiye ortaokul öğretim programlarından farklı olarak Uzaktan algılama tekniğinin kullanıldığı da söylenebilir.

\section{TARTIŞMA}

Doğa bugüne kadar birçok kez insanoğlunun hırsı ile yüzleşmek zorunda kalmış ve zaman zaman kendi kendini yenileyebilme başarısı göstermiştir. Fakat son yüz elli yıldır özellikle Sanayi Devrimi'nden bu yana beşeri faaliyetler sebebiyle daha da artan sera gazı emisyonları, küresel iklim değişikliğine karşı ülkeleri birlikte hareket etmeye ve ciddi önlemler almaya zorlamıştır. IPCC'nin çalışma gruplarına göre küresel iklim değişikliğine karşı geliştirilen iki temel strateji vardır: "İklim Değişikliğini Azaltım” ve "İklim Değişikliğine Uyum". Bu iki temel stratejinin odağında ise eğitim sektörü bulunmaktadır. İklim Değişikliği Eğitimi hem Çevre Eğitimi'nin, hem Sürdürülebilir Kalkınma Eğitimi'nin hem de Afet Riski Azaltma Eğitimi'nin bir parçası olarak son yıllarda kendi kimliğini oluşturmaya başlamış bir yaklaşımdır. Birçok ülke küresel iklim değişikliğini müfredat programlarında bazen disipliner bazen de disiplinlerarası bir yaklaşımla vermeye devam etmiş fakat son yıllarda Birleşmiş Milletlerin çağrısına uyarak küresel iklim değişikliğini, İklim Değişikliği Eğitimi yaklaşımına uygun olarak mevcut programlarına entegre etmeye başlamışlardır.

$\mathrm{Bu}$ anlamda ülkemizde iklim ve iklim değiş̧ikliği ile ilgili konuların iklim değişikliği eğitimi yaklaşımına göre ortaokul öğretim programlarında yer alması son derece önemlidir. Ancak, iklim değişikliği eğitimi yaklaşımını ortaokul öğretim programlarına entegre eden ülkelerin programları ile Türkiye programları karşılaştırıldığında bazı benzerlikler olmasına rağmen önemli farklılıklarla da karşılaşılmaktadır.

İklim değişikliği eğitiminin bileşenlerinden biri olan "iklim ve iklim değişikliği konularını içeren dersler disiplinlerarası olarak verilmelidir" ilkesinden hareketle araştırma kapsamında incelenen ülkelerden Kanada (British Columbia), ABD (Massachusetts), İspanya (Casttilla y Leon) ve Güney Afrika Cumhuriyeti ortaokul öğretim programlarında iklim ve iklim değişikliği ile ilgili konuların Türkiye ortaokul öğretim programlarında da olduğu gibi disiplinlerarası yaklaşımla verildiği; Almanya (Bavyera), Finlandiya, Avustralya (Western Australia) ve İngiltere ortaokul öğretim programlarında ise hem disipliner hem de disiplinlerarası yaklaşımla verildiği söylenebilir. Fakat İsveç ortaokul öğretim programlarında disipliner yaklaşımın öne çıktığı görülmektedir.

İklim değişikliği eğitiminin bir diğer bileşeni olan "İklim ve İklim Değişikliği ile ilgili hedef-kazanımlar öğrencilerde kavram yanılgılarına yol açmayacak biçimde düzenlenmelidir" ilkesine göre araştırma kapsamında incelenen ülkelerden özellikle Avustralya (Western Australia) ve Güney Afrika Cumhuriyeti'nde Türkiye ortaokul öğretim programlarından farklı olarak iklim sisteminin daha sistematik bir şekilde hedef-kazanımlarda yer aldığ 1 ifade edilebilir. 
İklim değişikliği eğitiminin bir diğer bileşeni olan "İklim değişikliğinin süreç ile iliş̧kisini öğretebilmek için öğrenciye yaparak-yaşayarak öğrenme faaliyetleri sunulmalıdır" ilkesine göre incelenen ülkelerin çoğunda Türkiye ortaokul öğretim programlarından farklı olarak öğrencilere basit meteorolojik veri analizlerinin yaptırıldığı özellikle İspanya (Castilla y Leon) ve Güney Afrika Cumhuriyeti'nde öğrencilerin ilgili kurumlardan veri toplayarak analiz etme gibi öğrenme faaliyetleri içerisinde yer aldığı söylenebilir.

İklim değişikliği eğitiminin bir diğer bileşeni olan "İklim Değişikliğinin etkileri yerel ve bölgesel olaylarla ilişkilendirilmelidir" ilkesine göre incelenen ülkelerin çoğunda iklim ve iklim değişikliği ile ilgili konuların yerel ve bölgesel unsurlarla ilişkilendirildiği ifade edilebilir. Fakat ABD (Massachusetts), Avustralya (Western Australia) ve Finlandiya'da Türkiye ortaokul öğretim programlarından farklı olarak kıtasal karşılaştırmalara da yer verildiği görülmektedir.

İklim değişikliği eğitiminin bir diğer bileşeni olan "İklim değişikliği eğitimi yaklaşımına uygun pedagojiler ve etkili materyaller içermelidir" ilkesinden hareketle incelenen ülkelerden Almanya (Bavyera), İngiltere, İsveç, Kanada (British Columbia) ve Güney Afrika Cumhuriyeti'nde Türkiye ortaokul ögretim programlarından farklı olarak Coğrafi Bilgi Sistemleri (CBS), Hava ve Uydu fotoğrafları, uzaktan algılama tekniği gibi UNESCO'nun önerdiği öğretme - öğrenme stratejilerinden faydalanıldı̆̆ 1 ifade edilebilir.

İklim değişikliği eğitiminin bir diğer bileşeni olan "İklim değişikliği eğitimi kaynakların sürdürülebilir kullanımın içermelidir" ilkesinden hareketle incelenen ülkelerden İsveç, Almanya (Bavyera), ABD (Massachusetts), Kanada (British Columbia), Avustralya (Western Australia), İspanya (Castilla y Leon), Güney Afrika Cumhuriyeti ve Finlandiya ortaokul öğretim programlarında iklim ve iklim değişikliği ile ilgili konularda Sürdürülebilir Kalkınmanın yer aldığı görülmektedir. Fakat İngiltere ve Türkiye ortaokul öğretim programlarında kaynakların sürdürülebilir kullanımının kısmen verildiği söylenebilir.

İklim değişikliği eğitimi, çevre eğitimi ve sürdürülebilir kalkınma eğitimi'nin bir parçası olarak kuramsal yapısını geliştirmeye devam etmektedir. $\mathrm{Bu}$ süreçle bağlantılı olarak iklim okuryazarlı̆̆ı, iklim sisteminin temel ilkelerini anlayan, iklim hakkında bilimsel olarak güvenilir bilgiyi nasıl değerlendireceğini bilen, iklim değişikliğinin etkilerini en aza indirebilecek bilinçli kararlar alabilen ve sürdürülebilir toplumların sağlanmasına yardımcı olacak şekilde hareket eden çevresel tutum ve davranışları gelişmiş bireyler yetiştirmeyi hedeflemektedir. Bu hedefleri gerçekleştirebilmek ancak iklim değişiliği eğitimi yaklaşımına göre tasarlanan öğretim programları ile sağlanabilir. Literatürde de vurgulandığı üzere iklim değişikliği eğitimi yaklaşımına göre dizayn edilen öğretim programları ihtiyacına rağmen, Türkiye'de bu ihtiyaca cevap verebilecek program geliştirme çalışmasına rastlanılmadığı gibi dünyadaki örnekleri de çok az sayıdadır. Bunun için de bu alanda yapılacak deneysel çalışmaların artırılması önerilmektedir.

Hakem Değerlendirmesi: Dış bağımsız.

Çıkar Çatışması: Yazarlar çıkar çatışması bildirmemiştir.

Finansal Destek: Yazarlar bu çalışma için finansal destek almadığını beyan etmiştir.

Peer-review: Externally peer-reviewed.

Conflict of Interest: The authors have no conflict of interest to declare.

Grant Support: The authors declared that this study has received no financial support.

\section{KAYNAKÇA/REFERENCES}

Alexandru, A., Ianculescu, M., Tudora, E., \& Bica, O. (2013). ICT challenges and issues in climate change education. Studies in Informatics and Control, 22(4), 349-358. http://dx.doi.org/10.24846/ v22i4y 201310

Anderson, A. (2010). Combating climate change through quality education. Washington, DC: Brookings Global Economy and Development.

Anderson, A. (2012). Climate change education for mitigation and adaptation. Journal of Education for Sustainable Development, 6(2), 191-206. http://dx.doi.org/10.1177/0973408212475199

Bagoly-Simó, P. (2013). Tracing sustainability: An international comparison of ESD implementation into lower secondary education. Journal of Education for Sustainable Development, 7(1), 95-112. http://dx.doi.org/10.1177/0973408213495610

Bamber, P., Bullivant, A., Glover, A., King, B., \& McCann, G. (2016). A comparative review of policy and practice for education for sustainable development/education for global citizenship (ESD/ GC) in teacher education across the four nations of the UK. Management in Education, 30(3), 112-120. http://dx.doi. org $/ 10.1177 / 0892020616653179$

Bangay, C., \& Blum, N. (2010). Education responses to climate change and quality: Two parts of the same agenda? International Journal of Educational Development, 30(4), 359-368. http://dx.doi.org/ 10.1016/j.ijedudev.2009.11.011

Bodlalo, L. H., Sabbaghan, M., \& Jome, S. M. R. E. (2013). A comparative study in green chemistry education curriculum in America and China. Procedia-Social and Behavioral Sciences, 90, 288-292. http://dx.doi.org/10.1016/j.sbspro.2013.07.093 
Chang, C. H., \& Pascua, L. (2017). The state of climate change education - reflections from a selection of studies around the world, International Research in Geographical and Environmental Education, 26(3), 177-179. http://dx.doi.org/10.1080/10382046.2017 .1331569

Choi, S., Niyogi, D., Shepardson, D., \& Charusombat, U. (2010). Do earth and environmental science textbooks promote middle and high school students' conceptual development about climate change? Textbooks' consideration of students' misconceptions. Bulletin of the American Meteorological Society, 91(7), 889-898. http://dx.doi.org/10.1175/2009BAMS2625.1

Derman, M. (2015). Farkl ülkelerin ilköğretim ve ortaöğretim fen bilimleri öğretim programlarında çevre eğitiminin karşılaştırmalı incelenmesi. (Doktora Tezi). Atatürk Üniversitesi Eğitim Bilimleri Enstitüsü, Erzurum.

Department for Education of United Kingdom. (2013). National curriculum in England: Framework for key stages 1 to 4. Retrieved from https:/www.gov.uk/government/publications/nationalcurriculum-in-england-geography-programmes-of-study/nationalcurriculum-in-england-geography-programmes-of-study

Department of Basic Education Republic of South Africa. (2011). Basic Education Curriculum of South Africa. Retrieved from http://www. thutong.doe.gov.za/Home/Curriculum/tabid/257/Default.aspx

Erdoğan, M., Kostova, Z., \& Marcinkowski, T. (2009). Components of Environmental Literacy in Elementary Science Education Curriculum in Bulgaria and Turkey. Eurasia Journal of Mathematics, Science \& Technology Education, 5(1), 15-26. Retrieved from https://pdfs.semanticscholar.org/e678/a66bb9c66e699ea90d 99e4b724b19185a417.pdf

Government of Western Australia. (2015) Western Australian Curriculum, Australia. Retrieved from https://k10outline.scsa.wa. edu.au/home/teaching/curriculum-browser

Haslett, S. K., Skellern, A., Chilcott, M., \& Longman, D. (2010). Pedagogy of Climate Change. In S. K. Haslett, D. France \& S. Gedye (Eds.), Climate change education through a blended learning Google Earth exercise (pp. 112-127), Publishing Higher Education Academy.

Ho, L. C., \& Seow, T. (2015). Teaching controversial issues in geography: Climate change education in Singaporean schools. Theory \& Research in Social Education, 43(3), 314-344. http://dx.doi.org/10.1080/00933104.2015.1064842

Huai-xin, Z., \& Dillon, J. (2001). Education for sustainable development: A Sino-English comparative study in environmental education. Journal of Zhejiang University-SCIENCE A, 2(3), 342347. http://dx.doi.org/10.1007/BF02839473

Johnson, R. (2011). Climate change education in K-12: Teacher preparation, understanding, needs and concerns. Slingerlands, NY: National Earth Science Teachers Association.

Kagawa, F., \& Selby, D. (2012). Ready for the storm: Education for disaster risk reduction and climate change adaptation and mitigation. Journal of Education for Sustainable Development, 6(2), 207-217. http://dx.doi.org/10.1177/0973408212475200
Kaya, M. F. ve Tomal, N. (2011). Sosyal bilgiler dersi öğretim programının sürdürülebilir kalkınma eğitimi açısından incelenmesi. Eğitim Bilimleri Araştırmaları Dergisi, 1(2), 49-65. Erişim adresi: https:// dergipark.org.tr/en/download/article-file/696392

Khalid, T. (2003). Pre-service high school teachers' perceptions of three environmental phenomena, Environmental Education Research, 9(1), 35-50. http://dx.doi.org/10.1080/13504620303466

Læssøe, J., Schnack, K., Breiting, S., Rolls, S., Feinstein, N., Goh, K. C., \& Jensen, B. B. (2009). Climate change and sustainable development: The response from education. A Cross-National Report, International Alliance of Leading Education Institutes. University of Aarhus, Denmark. Retrieved from https://edu.au.dk/ fileadmin/www.dpu.dk/en/research/researchprogrammes/ environmentalandhealtheducation/om-dpu_institutter_institut-fordidaktik_20091208102732_cross_national-report_dec09.pdf

Makrakis, V., Larios, N., \& Kaliantzi, G. (2012). ICT-enabled climate change education for sustainable development across the school curriculum. Journal of Teacher Education for Sustainability, 14(2), 54-72. http://dx.doi.org/10.2478/v10099-012-0009-5

Massachusetts Department of Elementary and Secondary Education. (2006). Massachusetts Curriculum Frameworks, USA. Retrieved from http://www.doe.mass.edu/educators/curriculum.html

Mckeown, R., \& Hopkins, C. (2003). EE p ESD: Defusing the worry. Environmental Education Research, 9(1), 117-128. http:// dx.doi.org/10.1080/13504620303469

McKeown, R., \& Hopkins, C. (2010). Rethinking climate change education. Green Teacher, (89), 17. Retrieved from https://www. humphreyfellowship.org/system/files/Rethinking\%20Climate $\% 20$ Change\%20Education.pdf

Milli Eğitim Bakanlığı. (2004). Sosyal bilgiler dersi ögretim programı, 5-67. sinıflar. Erişim adresi: http://mufredat.meb.gov.tr/Programlar.aspx

Milli Eğitim Bakanlığı. (2013). Fen ve teknoloji dersi ögretim programı, 5-6-7-8. sinıflar. Erişim adresi: http://mufredat.meb.gov.tr/ Programlar.aspx

Ministeri D’educació I Ciència \&,Munidad Junta de Castilla y Leon. (2007). Disposiciones generales curriculo. Retrieved from https:// www.educa.jcyl.es/es/curriculo

Finnish National Board Of Education. (2004). National Core Curriculum for Basic Education. Retrieved from https://www.oph.fi/english/ curricula_and_qualifications/basic_education/curricula_2014

Ministry of Education British Columbia. (2005). The British Columbia Secondary School Curriculum, Canada. Retrieved from https:// www2.gov.bc.ca/gov/content/education-training/k-12/teach/ curriculum/english

Mochizuki, Y., \& Bryan, A. (2015). Climate change education in the context of education for sustainable development: Rationale and principles. Journal of Education for Sustainable Development, 9(1), 4-26. http://dx.doi.org/10.1177/0973408215569109

National Research Council. (2011). Climate change education: Goals, audiences, and strategies: A workshop summary. Washington, DC: The National Academies Press. http://dx.doi.org/10.17226/13224 
Nazir, J., Pedretti, E., Wallace, J., Montemurro, D., \& Inwood, H. (2011). Reflections on the Canadian experience with education for climate change and sustainable development. Canadian Journal of Science, Mathematics and Technology Education, 11(4), 365-380. http://dx.doi.org/10.1080/14926156.2011.624673

Niepold, F., Herring, D., \& McConville, D. (2008) The role of narrative and geospatial visualization in fostering climate literate citizens. Physical Geography, 29 (6), 529-544. http://dx.doi. org/10.2747/0272-3646.29.6.529

Nussbaum, E. M., Owens, M. C., Sinatra, G. M., Rehmat, A. P., Cordova, J. R., Ahmad, S., Harris, F. C., \& Dascalu, S. M. (2015). Losing the Lake: Simulations to promote gains in student knowledge and interest about climate change. International Journal of Environmental and Science Education, 10(6), 789-811. Retrieved from https://files.eric.ed.gov/fulltext/EJ1082016.pdf

Oversby, J. (2015). Teachers' learning about climate change education. Procedia-Social and Behavioral Sciences, 167, 23-27. http://dx.doi.org/10.1016/j.sbspro.2014.12.637

Özata, Y. ve Özkan, M. (2013). 2013 Fen bilimleri programının 2005 fen ve teknoloji programıla çevre konuları açısından karş1laştırılması. Uludağ Üniversitesi Ĕgitim Fakültesi Dergisi, 26(1), 237-266. Erişim adresi: https://dergipark.org.tr/en/ download/article-file/153502

Özkaral, T. C. (2019). Küresel 1sınma ve iklim değişikliği konusunun Türkiye, Kanada (Ontario) ve Hong Kong sosyal bilgiler öğretim programlarında karşılaştırmalı olarak incelenmesi. International Journal of Education Technology and Scientific Researches. 4(8), 1-14.Erişimadresi:http://ijetsar.com/Makaleler/1487572266_1.\%20 1-14\%20tu\%c4\%9fba\%20cevriye \%20\%c3\%b6zkaral.pdf

Pruneau, D., Liboiron, L., Vrain, É., Gravel, H., Bourque, W., \& Langis, J. (2001). People's ideas about climate change: A source of inspiration for the creation of educational programs. Canadian Journal of Environmental Education, 6, 121-138. Retrieved from https://files.eric.ed.gov/fulltext/EJ661764.pdf

Pruneau, D., Gravel, H., Bourque, W., \& Langis, J. (2003). Experimentation with a socio-constructivist process for climate change education. Environmental Education Research, 9(4), 429446. http://dx.doi.org/10.1080/1350462032000126096

Pruneau, D., Khattabi, A., \& Demers, M. (2010). Challenges and possibilities in climate change education. Online Submission, 7(9), 15-24. Retrieved from https://files.eric.ed.gov/fulltext/ED514727. pdf

Robinson, Z. (2011). Pedagogy of Climate Change. In S. K. Haslett, D. France \& S. Gedye (Eds.), Teaching climate change in higher education: barriers and opportunities (pp. 36-50). Publishing Higher Education Academy.

Shepardson, D. P., Niyogi, D., Roychoudhury, A., \& Hirsch, A. (2012). Conceptualizing climate change in the context of a climate system: Implications for climate and environmental education. Environmental Education Research, 18(3), 323-352. http://dx.doi.org/10.1080/135 04622.2011 .622839
Srbinovski, M., Erdogan, M., \& Ismaili, M. (2010). Environmental literacy in the science education curriculum in Macedonia and Turkey. Procedia-Social and Behavioral Sciences, 2(2), 4528-4532. http://dx.doi.org/10.1016/j.sbspro.2010.03.725

Staatsinstitut für Schulqualität und Bildungsforschung München. (2009). Gymnasium Lehrplan für Bayerische. Retrieved from http:// www.isb.bayern.de/gymnasium/faecher/

The Swedish National Agency for Education. (2012). National secondary school curriculum of Sweden. Retrieved from https:// www.skolverket.se/undervisning

Tong, T. M. T., Shaw, R., \& Takeuchi, Y. (2012). Climate disaster resilience of the education sector in Thua Thien Hue Province, Central Vietnam. Natural Hazards, 63(2), 685-709. http://dx.doi. org/10.1007/s11069-012-0178-5

United Nations Conference on Environment and Development. (1992). Agenda 21: Programme of Action for Sustainable Development; Rio Declaration on Environment and Development; Statements of Forest Principles; the Final Text of Agreements Negotiated by Governments at the United Nations Conference on Environment and Development (UNCED). 3-14 June 1992, Rio de Janeiro/Brazil: Publishing United Nations Department of Public Information. Retrieved from https:// unesdoc.unesco.org/ark:/48223/pf0000116639

United Nations Environment Programme. (2006). Raising awareness of climate change: A handbook for government focal points. Switzerland: Publishing UNEP/DELC. Retrieved from http:// wedocs.unep.org/bitstream/handle/20.500.11822/8617/unep_cc_ handbook.pdf? sequence $=3$ \&isAllowed $=\mathrm{y}$

United Nations Educational, Scientific and Cultural Organization. (2009a). International seminar on climate change education: report. 27-29 July 2009, Paris/France. Retrieved from http://www. unesco.org/science/doc/cc/CC_seminar_report_071209.pdf

United Nations Educational, Scientific and Cultural Organization. (2009b). Education for sustainable development and climate change. Policy Dialogue 4: ESD and Development Policy. ED2009/WS/10, Paris, France: Publishing UNESCO. Retrieved from https://unesdoc.unesco.org/ark:/48223/pf0000179122

United Nations Educational, Scientific and Cultural Organization. (2015). Not just hot air: Putting climate change education into practice. Paris/France: Publishing UNESCO. Retrieved from https://unesdoc.unesco.org/ark:/48223/pf0000233083

United Nations Educational, Scientific and Cultural Organization \& United Nations Environment Programme. (2011). Climate change starter's guidebook: an issues guide for educational planners and practitioners. Paris/France: Publishing UNESCO/UNEP. Retrieved from (http://unesdoc.unesco.org/images/0021/002111/211136E.pdf United Nations Department of Public Information. (1994). Article 6: Education, training and public awareness. United Nations Framework Convention on Climate Change. New York: Publishing UN. Retrieved from https://unfccc.int/resource/docs/convkp/ conveng.pdf 
United States Global Change Research Program. (2009). Climate literacy: the essential principles of climate science. Washington, DC. Retrieved from https://cpo.noaa.gov/Portals/0/docs/ MeettheDivisions/ClimateLiteracyPoster-8_5x11_Final4-11LR.pdf

Wise, S. B. (2010). Climate change in the classroom: Patterns, motivations, and barriers to instruction among Colorado science teachers. Journal of Geoscience Education, 58(5), 297-309. https:// doi.org/10.5408/1.3559695

Yakar, H., \& Karakuş, U. (2019). Investigation of the social studies curricula in Turkey (1968-2018) with regards to the climate literacy principles. Universal Journal of Educational Research, 7(5), 12161225. http://dx.doi.org/10.13189/ujer.2019.070507
Yıldırım, A. ve Şimşek, H. (2013). Sosyal bilimlerde nitel araştırma yöntemleri (9.bs). Ankara: Seçkin Yayıncılık.

Yolcu, O. (2014). Cumhuriyetten (1923) günümüze (2013) ilköğretim birinci kademe hayat bilgisi ve fen ve teknoloji öğretim programlarının "çevre eğitimi" açısından incelenmesi. (Yükssek Lisans Tezi). Adnan Menderes Üniversitesi Sosyal Bilimler Enstitüsü, Aydın. 
